REVIEW

\title{
Physiological Roles of Corticotropin-Releasing Hormone Receptor Type 2
}

\author{
Kozo HASHIMOTO, Shinya MAKINO*, KoIchi ASABA and Mitsuru NISHIYAMA \\ Second Department of Internal Medicine, Kochi Medical School, Kochi 783-8505, Japan \\ * Department of Internal Medicine, Osaka Gyomeikan Hospital, Osaka 554-0022, Japan
}

\section{Introduction}

Corticotropin-releasing hormone $(\mathrm{CRH})$ is a key mediator of endocrine, autonomic, behavioral, and immune responses to stress. In response to stress, $\mathrm{CRH}$ released from the hypothalamic paraventricular nucleus (PVN) activates $\mathrm{CRH}$ receptor on the anterior pituitary corticotrophes, resulting in secretion of adrenocorticotropic hormone (ACTH) into the bloodstream. Two CRH receptors, $\mathrm{CRH}$-receptor type 1 (CRH-R1) and type 2 (CRH-R2), have been cloned [1-4]. CRH-R1 is highly expressed in the anterior pituitary, neocortex, olfactory bulb, hippocampus, amygdala, septum and relay nuclei of the brain stem and hypothalamus [5]. CRH-R2 is expressed in more limited brain areas than is CRH-R1. In the rodent, one splice variant form of the $\mathrm{CRH}$ $\mathrm{R} 2, \mathrm{CRH}-\mathrm{R} 2 \alpha$ is expressed mainly in the brain, especially in the hypothalamic ventromedial nucleus (VMH) and PVN, lateral septic nucleus, and medial amygdaloid nucleus [6]. An other variant form, $\mathrm{CRH}-\mathrm{R} 2 \beta$, is expressed mainly in the peripheral tissue as well as in the brain. It is expressed at high levels in the heart and skeletal muscles and at low levels in the lung and intestine $[4,6]$. In contrast to rodents, human CRH-R $2 \beta$ is only weakly expressed in the heart and skeletal muscles, whereas CRH-R $2 \alpha$ is predominant [7]. More recently, an additional variant of CRH-R2, CRH-R2 $\gamma$, was found in human [8].

The poor correlation between the sites of $\mathrm{CRH}$ and

Mailing address: Kozo HASHIMOTO, M.D., Second Department of Internal Medicine, Kochi Medical School, Kohasu, Okoh-cho, Nankoku, Kochi 783-8505, Japan
CRH-R2 expression, as well as the relatively low affinity of CRH for CRH-R2, suggested the presence of another ligand for CRH-R2, paving the way for the discovery of urocortin (UCN) [9-10]. UCN is $43 \%$ homologous to $\mathrm{CRH}$ and has high affinity to CRH-R2. UCN is mainly found in the brain-stem Edinger-Westphal nucleus, and also found in the hippocampus, lateral septum, amygdala, neocortex, and nucleus tractus solitarius [11]. It is also found in peripheral sites such as the duodenum, uterus, and lymphocytes. Intracerebroventricular (icv) administration of UCN elicits a strong anorexic effect. When it is injected peripherally it reduces blood pressure [12]. As UCN has greater affinity to CRH$\mathrm{R} 2$ than does $\mathrm{CRH}$, it is assumed that $\mathrm{UCN}$ is an endogenous ligand to CRH-R2. It is accepted that the effects of CRH and UCN may be mediated via either CRH-R1 or CRH-R2, or both. However, CRH-R1 and CRH-R2 could be detected only weakly in brain areas such as the central amygdala, Edinger-Westphal nucleus and locus coeruleus, these sites being the major brain sources of $\mathrm{CRH}$ and $\mathrm{UCN}$ or target areas of these neuropeptides' action. Therefore, the existence of other yet undiscovered $\mathrm{CRH}$ related peptides are proposed [13, 14].

Corticotropin-releasing hormone binding protein (CRH-BP), which binds $\mathrm{CRH}$ and UCN with affinities greater than CRH-R1 and CRH-R2, shows a broad distribution in the brain [15]. Colocalization of CRH-BP and CRH, UCN or CRH receptors has been observed in some brain areas. Therefore, free CRH and UCN, which do not bind to CRH-BP, are the active forms that play physiological roles in the brain.

Many experiments have been done to clarify which 
subtype of CRH receptors is involved in the activities of $\mathrm{CRH}$ and UCN. It has been relatively well established that CRH-R1 is involved in HPA axis activation [16-19] and in the stress-induced enhancement of anxiety, fear and learning [18-21]. However, the physiological roles of CRH-R2 and its endogenous ligand have not been fully elucidated. To elucidate the role of CRH-R2, many kinds of techniques have been used. The in situ hybridization method has been used to examine the regulation of VMH CRHR2 mRNA expression. Non-selective or selective CRH-R1 and/or CRH-R2 antagonists, and antisense oligonucleotides against CRH-R1 or CRH-R2 have been administered to animals to see the way in which they prevented the actions of CRH or UCN. Very recently, CRH-R2 knockout mice have been developed to clarify the physiological role of CRH-R2. In this review, the results of these recent investigations are summarized.

\section{Hypothalamic-pituitary-adrenal (HPA) axis regulation}

As CRH-R2 $\alpha$ showed a relatively high expression in the hypothalamic PVN, it was speculated that CRH-R $2 \alpha$ might be involved in the autoregulation of $\mathrm{CRH}$ secretion in the PVN. However, CRH-R2 $\alpha$ was revealed to localize mainly in the magnocellular part of the PVN [22], and icv injection of CRH sig- nificantly increased $\mathrm{CRH}-\mathrm{R} 1$ but did not change CRH-R2 mRNA levels in the PVN [23]. Lipopolysaccharide injection (LPS) induced a significant increase in PVN CRH-R1 mRNA (Fig. 1), while CORT administration or adrenalectomy decreased CRH-R1 mRNA levels. In contrast, CRH-R $2 \alpha$ mRNA levels in the PVN were not altered by these manipulations [23]. CRH-R2 knockout mice did not show any changes in pituitary corticotrophs and the adrenal cortex $[24,25]$, though CRH-R1 knockout mice showed a marked reduction in adrenal zona fasciculata [19]. These results indicate that CRH-R2 does not play an important role in HPA axis regulation. On the other hand, Smagin et al. [26] reported that icv administration of anti-sense oligonucleotide to CRH-R2 mRNA significantly attenuated CRHand UCN-induced HPA activation, suggesting stimulatory effects of exogenously administrated $\mathrm{CRH}$ and UCN on HPA axis are at least partly mediated by CRH-R2. However, mice deficient for CRH-R2 showed hyperresponse of ACTH and CORT to restraint stress $[24,25]$, and it has been postulated that CRH-R2 is involved in physiological adaptation to stresses. Kishimoto et al. [27], however, did not detect ACTH or CORT hyperresponse to stress in the CRH-R2 deficient mice they developed. Whether CRH-R2 is actually involved in HPA axis regulation remains to be clarified.
A

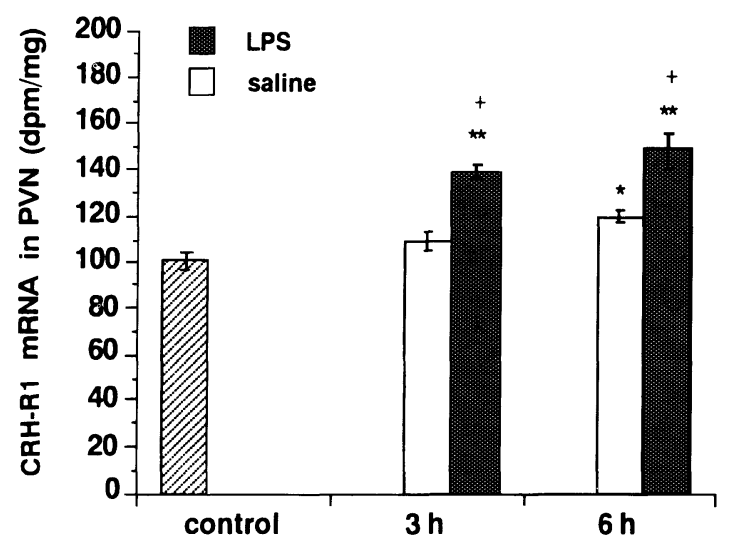

B

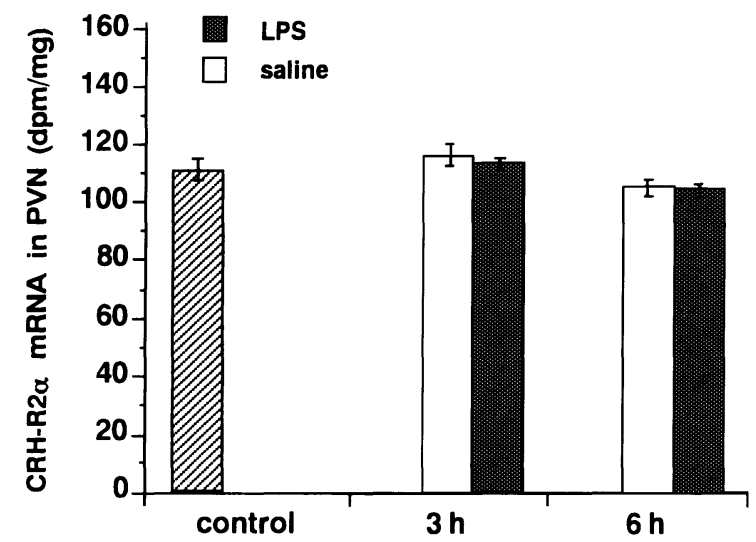

Fig. 1. CRH-R1 (A) and CRH-R2 $\alpha$ (B) mRNA hybridization levels in the PVN after i.p. lipopolysaccharide (LPS) or saline injection. Values are mean \pm S.E.M. ${ }^{*} \mathrm{p}<0.05$ vs. control, ${ }^{* *} \mathrm{p}<0.01$ vs. control, ${ }^{+} \mathrm{p}<1.001$ vs. saline group. (Reproduced from Ref. 23 with permission of the publisher) 


\section{Feeding and body weight regulation}

Restraint-induced hypophagia and body weight loss was prevented by icv administration of nonselective CRH receptor antagonist, $\alpha$-helical CRF (941) [28]. Hotta et al. [29] reported that emotional stress-induced inhibition of food intake was reversed by both icv injection of $\alpha$-helical CRF (9-41) and intraperitoneal injection of a selective non-peptidic CRF-R1 antagonist, CRA 1000, and suggested that CRH-R1 mediates at least in part the emotional stress-induced reduction of feeding behavior. On the contrary, administration of a selective CRH-R 1 receptor antagonist, NBI 27,914, did not affect icv $\mathrm{CRH}$-induced decrease in food intake [26], and a selective CRH-R1 agonist, antalarmin, did not affect body weight, carbohydrate metabolism, or leptin expression [16]. CRH-R1 knockout mice and wild type mice showed no difference in total amount of food intake. Although there was a significant disruption in the circadian distribution of food intake, with CRH-R1-deficient mice consuming significantly more food during the light period than the dark period, the normal diurnal pattern could be completely restored by oral administration of CORT [30]. These results suggest that CRH-R1 is not likely to play a critical role in feeding behavior, although some discrepancies among reports remain to be clarified.

On the other hand, $\mathrm{CRH}$-induced anorexia was significantly attenuated by the CRH-R2-selective antagonist antisauvagine-30 [31, 32]. As CRH-R2 mRNA is highly expressed in the VMH, classically referred to as the satiety center, we speculated that anorexiogenic effects of $\mathrm{CRH}$ or $\mathrm{UCN}$ are transduced via CRH-R2 in the VMH. Starvation and adrenalectomy, each of which lowered plasma insulin and leptin levels, were associated with decrements in CRH-R2 mRNA levels in VMH but not in PVH (Fig.

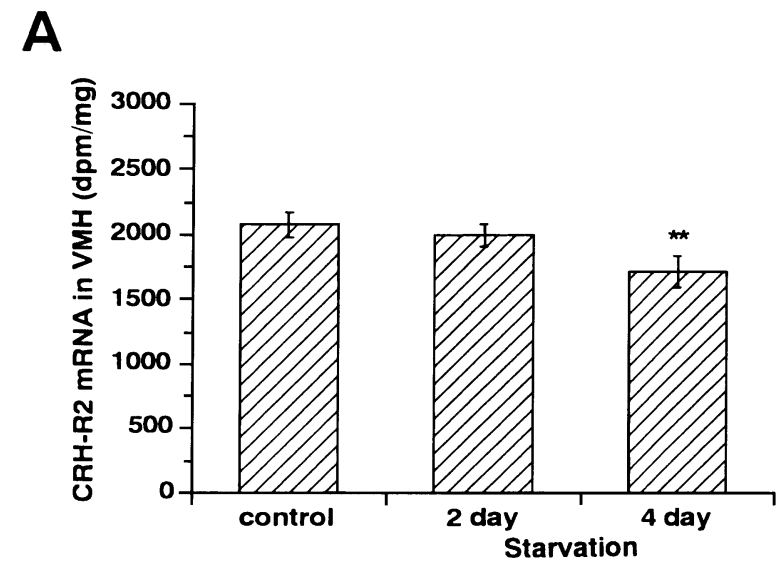

B
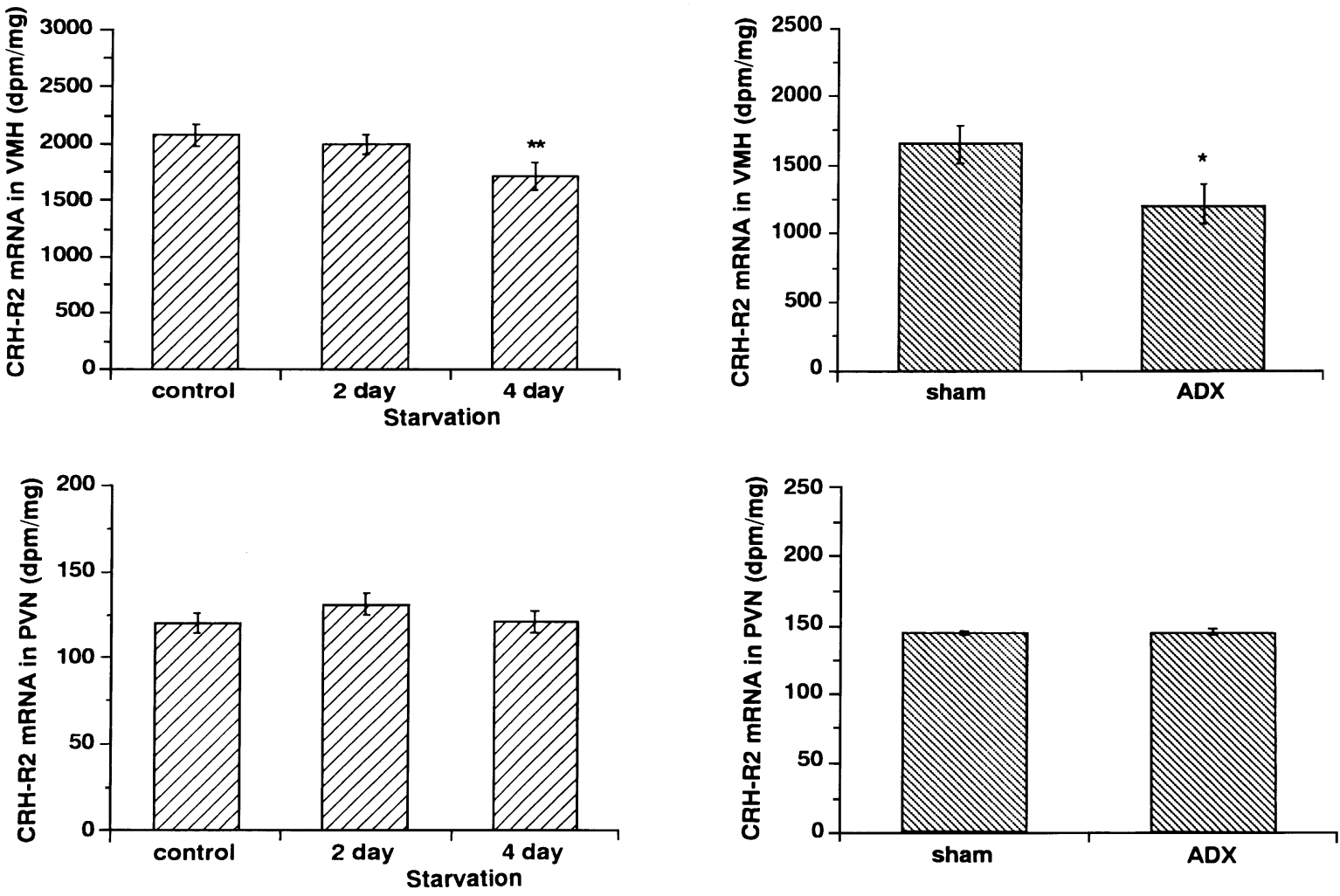

Fig. 2. Hybridization levels of CRH-R2 mRNA in the VMH and PVN after starvation for 2 or 4 days (A) and adrenalectomy (B). Values are means \pm SME. ${ }^{*} p<0.05$ vs. control group (A) or sham group (B). (Reproduced from Ref. 33 with permission of the publisher) 
2) [33]. The concordance of a fall in plasma insulin and leptin levels with the fall in VMH CRH-R2 mRNA levels during starvation and adrenalectomy supports the idea that compensatory responses under the conditions of starvation and adrenalectomy include not only the disinhibiting effects of reduced insulin and leptin levels on appetite through already reported mechanisms but also via an effect of reduced leptin on VMH CRH-R2. A single intraperitoneal or continuous subcutaneous injection of leptin increased CRH-R2 mRNA levels in the rat VMH (Fig. 3) [34], suggesting that the anorexic effect of leptin may be transduced by upregulation of CRH-R2 mRNA. A large amount of CORT administration, which induces food and body weight reduction, also upregulates CRH-R2 mRNA [34]. Rats immobilized for $2 \mathrm{hr}$ daily for 6 days reduced their food intake and body weight. Repeated daily immobilization increased PVN CRH mRNA and lowered plasma insulin and leptin concentrations as well as VMH CRH-R2 mRNA levels [35]. Low leptin and VMH CRH-R2 mRNA levels may also produce counterregulatory responses against the anorexic effects of CRH or UCN. These results provide additional evidence linking plasma leptin and VMH CRH-R2 mRNA. Richard et al. [36] reported that expression of the CRH-R2 transcript was reduced in the VMH of obese rats.

Recently it has been reported that mice deficient for CRH-R2 express normal basal feeding and weight
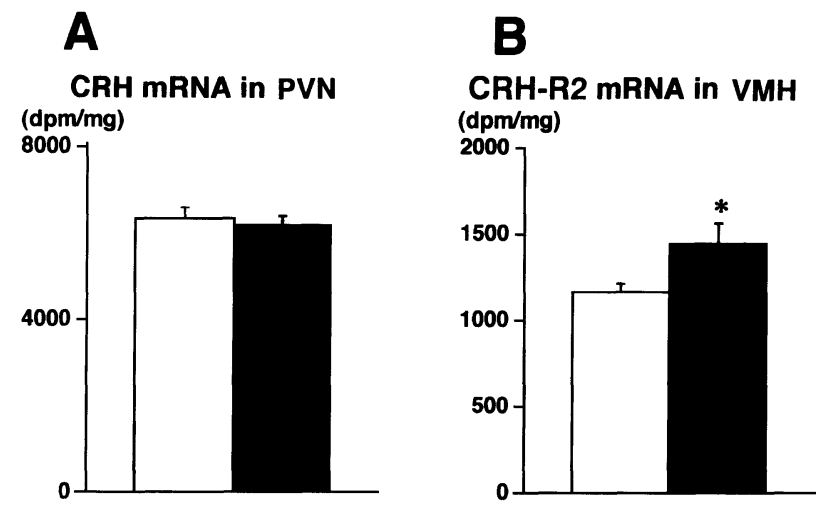

Fig. 3. Hybridization levels of CRH mRNA in the PVN (A) and CRH-R2 mRNA in the VMH (B) of vehicle- and leptin- $(1.2 \mathrm{mg} / \mathrm{kg} /$ day) treated rats following a continuous 5-day infusion via an osmotic minipump. Values are means \pm SEM. ${ }^{*} \mathrm{p}<0.05,{ }^{* *} \mathrm{p}<0.01$ vs. vehicle group. (Reproduced from Ref. 34 with permission of the publisher) gain. UCN initially suppressed food intake in these mice, but they recover food intake more rapidly and completely than do wild-type mice. These results suggest that CRH-R2 is essential for sustained feeding suppression induced by UCN. Injection of antirat UCN rabbit $\gamma$-globulin into the bilateral VMH in freely fed rats significantly potentiated food and water intake compared with rats that received normal rabbit $\gamma$-globulin, suggesting that endogenous UCN in the VMH exert inhibitory control on ingestive behavior [37]. It is likely that VMH CRH-R2 is more important than CRH-R1 in mediating the anorexic effect of CRH, UCN, or unknown CRH-related peptides, and that stress-induced reduction of food intake is transduced by CRH-R2, though this remains to be confirmed. On the other hand, it has been reported that in the immature rat, CRH-R2 mRNA levels in VMH are governed primarily by maternal or suckling-derived sensory input rather than by food intake or peripheral stress hormones [38].

\section{Anxiolytic role}

It has been suggested that CRH mediates behavioral responses caused by stress. CRH increased anxiety [39, 40], startle response [41], and grooming [42], and decreased explorative behavior [43], though it has not been fully clarified which subtype of receptors is involved in these responses. A selective non-peptide CRH-R1 antagonist, antalarmin, impaired both the induction and expression of conditioned fear [17, 44]. Other selective nonpeptide CRH-R1 antagonists CP-154,526 [45, 46], CRA 1000, and CRA 1001 [47], also showed anxiolyticand antidepressant-like properties in various experimental models. Chronic infusion of CRH-R1 antisense oligonucleotide into the rat brain also caused an anxiolytic-like effect [20]. CRH-R1 deficient mice displayed markedly reduced anxiety $[18,19]$. These results all suggest that CRH-R1 plays a key role in mediating anxiety-related behavior. However, Radulovic et al. [21] observed by using a selective CRH-R2 antagonist, anti-sauvagine 30, that a high dose of $\mathrm{CRH}$ induced anxiety in rats probably via septal CRH-R2, which remains to be clarified.

In contrast, CRH-R2 knockout mice exhibited enhanced anxiety-like behavior in several anxiety tests, such as dark-light emergence task test and plus-maze 
test $[25,27]$. The enhanced anxiety of CRH-R2deficient mice was not due to changes in hypothalamic-pituitary-adrenal axis activity, but rather reflects impaired responses in specific brain regions [27]. Neither was it due to altered locomotor activity, because CRH-R2-deficient mice or mice given CRH-R2 antisense oligonucleotide did not show changes in overall locomotor activity [20, 25, 27]. These results suggest that CRH-R2 predominantly mediates a central anxiolytic response, opposing the anxiogenic effect of CRH mediated by CRH-R1. CRH-R2 seems to play a role counterregulatory to that of CRH-R1.

\section{Learning and memory}

The modulation of learning and memory seems to be one of the major roles of CRH in the brain. Injection of $\mathrm{CRH}$ into the dorsal hippocampus enhanced learning before and after training, and this effect was prevented by the local injection of the nonselective CRH-R1 antagonist astressin but not by the CRH-R2 specific antagonist antisauvagine-30 [21]. Therefore, hippocampal CRH-R1 may mediate stress-induced enhancement of learning. In contrast, injection of $\mathrm{CRH}$ into the lateral intermediate septum impaired learning, which was blocked by antisauvagine-30. When antisauvagine-30 was injected alone into the lateral intermediate septum, learning was enhanced. These results suggest that CRH-R2 in the lateral intermediate septum plays a part in the impairment of learning. The existence of two receptors that mediate opposite effects provides the CRH system with high flexibility and a dynamic role in the adaptation of the CNS to environmental challenge [21].

\section{Cardiovascular regulation}

Icv administration of CRH mimics stress-induced elevation of blood pressure and heart rate as well as the elevation of plasma norepinephrine (NE) and epinephrine (E) levels [48]. Although the CRHinduced cardiovascular effect was attenuated by pretreatment with a nonselective CRH-R antagonist, a-helical CRF (9-41) [49], it was unclear which type of CRH receptor was responsible for the CRH- induced autonomic responses. Icv treatment of a selective CRH-R1 antagonist, CP-154526 did not affect baseline heart rate, plasma $\mathrm{NE}$ and $\mathrm{E}$ levels, whereas it partially blocked the CRH-induced increase in heart rates and plasma NE and E levels, indicating that $\mathrm{CRH}$ activates the sympathetic nervous system at least in part via CRH-R1 [50].

In the rodent, CRH-R2 mRNA is found in peripheral tissues, especially in the heart and skeletal muscle, while CRH-R1 mRNA is undetectable in the heart. CRH-R2 mRNA expression in the heart is regulated by systemic administration of UCN, CORT, and cytokines [51, 52]. Systemic injection of LPS markedly downregulated CRH-R2 mRNA levels in the heart in a dose- and time-dependent manner, while CRH-R2 mRNA levels in skeletal muscle increased following exposure to endotoxin, suggesting that CRH-R2 may be differentially regulated in cardiac tissue and skeletal muscle [53].

CRH-R2 mRNA levels in spontaneously hypertensive rats (SHR) were significantly higher than those in normotensive controls. In contrast, $\mathrm{CRH}$ R2 mRNA levels in the hearts of deoxycorticosterone acetate (DOCA)-salt hypertensive rats were significantly lower than that of sham-operated controls after 6 weeks of treatment (Fig. 4) [54]. Although the mechanisms governing the changes of $\mathrm{CRH}-\mathrm{R} 2$ mRNA may differ in these hypertensive models, these results also suggest some roles of CRH-R2 in blood pressure regulation. CRH-R2-deficient mice showed elevated mean arterial pressure (MAP) and diastolic pressure compared with wild-type mice [24]. Systemic UCN administration decreases MAP in intact rats [10], but not in CRH-R2-deficient rats [24, 25]. These results suggest that peripheral CRH-R2 mediates the hypotensive effect of systemically administered UCN.

UCN stimulated atrial natriuretic peptide (ANP) and brain natriuretic peptide (BNP) secretions from neonatal rat cardiomyocytes [55]. It also stimulated leucine uptake into neonatal rat cardiomyocytes and potentiated the endothelin-induced increase of leucine uptake. CRH-R2 may be involved in UCNinduced ANP and BNP secretions. However, the physiological role of CRH-R2 in the heart remains to be clarified. 
A CRH-R2 mRNA in heart

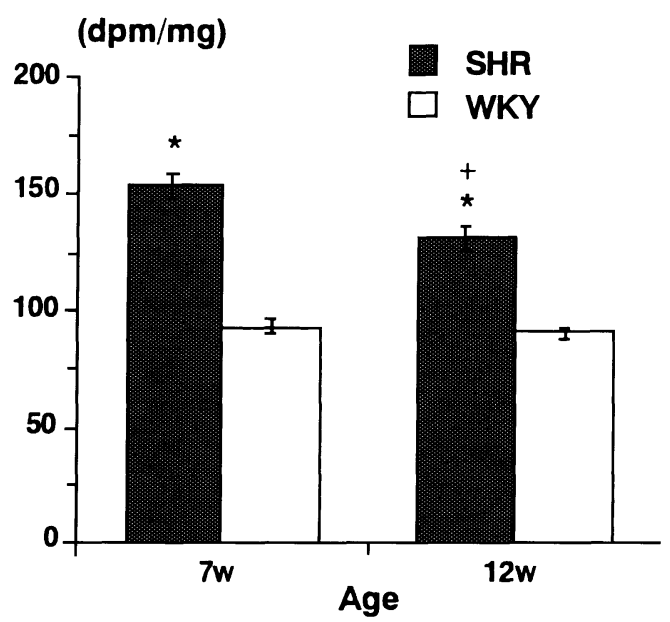

B CRH-R2 mRNA in heart

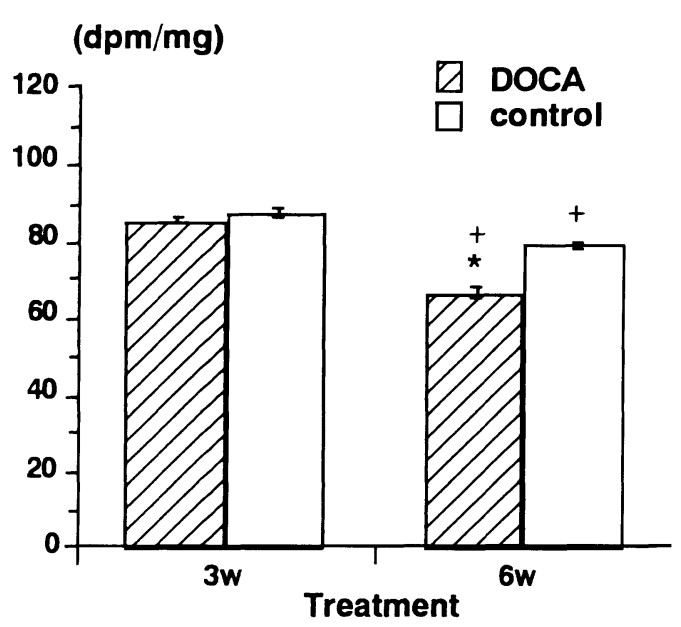

Fig. 4. Hybridization levels in the heart of SHR (A) and DOCA-salt hypertensive rats (B). Values are means \pm SEM. ${ }^{*} \mathrm{p}<0.01$ vs. WKY (A) or control (B). ${ }^{+} \mathrm{p}<0.01$ vs. 7-week-old SHR (A) or 3-week-treatment. (Reproduced from Ref. 54 with permission of the publisher)

\section{Other roles of CRH-R2}

Intravenous administration of $\mathrm{CRH}$ and UCN causes an inhibition of gastric emptying, which is fully reversed by the non-selective CRH receptor antagonist, astressin [56]. Astressin also completely prevented abdominal surgery-induced inhibition of gastric emptying, while the selective nonpeptide CRH-R1 antagonists antalarmin and NBI-27914 did not prevent $\mathrm{CRH}$ - and UCN-induced delay of gastric emptying. These results suggest that peripheral CRH-R2 is involved in intravenous CRH-, UCN- and abdominal surgery-induced gastric stasis. CRH-R2 is also involved in the central CRH-induced delay of gastric emptying [57].

Intradermal UCN at a concentration as low as $10 \mathrm{nM}$ induced skin mast cell degranulation and increased vascular permeability in rats [58]. Both the selective nonpeptide CRH-R1 antagonist, antalar$\mathrm{min}$, and the nonselective peptide antagonist, astressin, reduced UCN-induced vascular permeability, but not completely, suggesting that UCN-induced skin mast cell degranulation and subsequent vascular permeability in rodents may involve a $\mathrm{CRH}$ receptor other than the known CRH-R1, CRH-R $2 \alpha$, and CRH-R2 $\beta$ subtypes. A possible candidate may be the $\mathrm{CRH}-\mathrm{R} 2 \gamma$, which has been identified in human brain tissue [8].

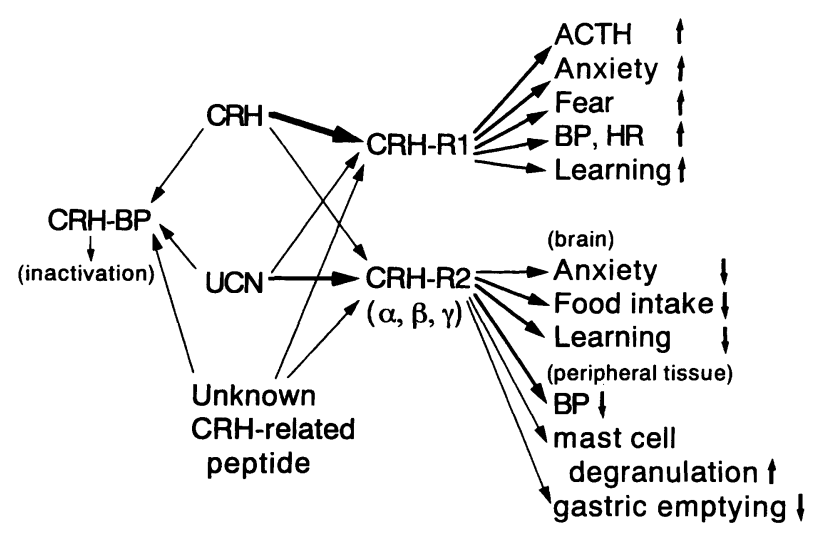

Fig. 5. Relationship among $\mathrm{CRH}$-related peptides, their receptors and their physiological roles. CRH-BP: corticotropin-releasing hormone binding protein, UCN: urocortin, CRH-R1: CRH receptor type 1, BP: blood pressure, HR: heart rate.

\section{Summary}

Recent investigations of the physiological roles of CRH-R2 are reviewed and summarized in Fig. 5. VMH CRH-R2 is more important than CRH-R1 in mediating anorexic effect of $\mathrm{CRH}$ or urocortin (UCN) and stress-induced reduction of food intake. CRH-R2 mediates a central anxiolytic response, opposing the anxiogenic effect of CRH mediated by CRH-R1. Hippocampal CRH-R1 mediates stressinduced enhancement of learning, while CRH-R2 in 
the lateral intermediate septum may act to impair learning. CRH-R1 mediates $\mathrm{CRH}$-induced blood pressure elevation, while peripheral CRH-R2 mediates the hypotensive effect of systemically administered UCN and CRH. It is likely that CRH-R2 does not play an important role in hypothalamicpituitary adrenal axis regulation, though it has been reported that CRH-R2-deficient mice showed hyperresponse of ACTH and corticosterone. Peripheral
CRH-R2 mediates UCN-induced mast cell degranulation, vascular permeability, and abdominal surgery-induced gastric stasis. These recent investigations have revealed that the existence of two $\mathrm{CRH}$ receptors, which mediate some opposite effects, provides the CRH and UCN systems a high flexibility and dynamic role in the adaptation of the body to environmental challenge.

\section{References}

1. Perrin MH, Donaldson CJ, Chen R, Lewis KA, Vale WW (1993) Cloning and functional expression of a rat brain corticotropin-releasing factor (CRF) receptor. Endocrinology 133: 3058-3061.

2. Lovenberg TW, Liaw CW, Grigoriadis DE, Clevenger W, Chalmers DT, De Souza EB, Oltersdorf T (1995) Cloning and characterization of a functionally distinct corticotropin-releasing factor receptor subtype from rat brain. Proc Natl Acad Sci USA 92: 836-840.

3. Liaw CW, Lovenberg TW, Barry G, Oltersdorf T, Grigoriadis DE, De Souza EB (1996) Cloning and characterization of the human corticotropin-releasing factor-2 receptor complementary deoxyribonucleic acid. Endocrinology 137: 72-77.

4. Perrin M, Donaldson C, Chen R, Blount A, Berggren T, Bilezikjian L, Sawchenko P, Vale W (1995) Identification of a second corticotropin-releasing factor gene and characterization of a cDNA expressed in heart. Proc Natl Acad Sci USA 92: 2969-2973.

5. Wong M-L, Licinio J, Pasternak KI, Gold PW (1994) Localization of corticotropin-releasing hormone receptor mRNA in adult rat brain by in situ hybridization histochemistry. Endocrinology 135: 2275-2278.

6. Lovenberg TW, Chalmers CW, Liu C, De Souza EB (1995) CRF2 $\alpha$ and CRF2 $\beta$ receptor mRNAs are differentially distributed between the rat central nervous system and peripheral tissues. Endocrinology 136: 4139-4142.

7. Valdenaire O, Giller T, Breu V, Gottowik J, Kilpatrick $G$ (1997) A new functional isoform of the human CRF2 receptor for corticotropin-releasing factor. Biochem Biophys Acta 1352: 129-132.

8. Kostich W, Chen A, Sperle K, Largent BL (1998) Molecular identification of a novel human corticotropin-releasing factor (CRF) receptor: the CRF2gamma receptor. Mol Endocrinol 12: 1077-1085.

9. Donaldson CJ, Sutton SW, Perrin MH, Corrigan AZ, Lewis KA, Rivier JE, Vaughan JM, Vale W (1995) Cloning and characterization of human uro- cortin. Endocrinology 137: 2167-2170.

10. Vaughan J, Donaldson C, Bittencourt J, Perrin $\mathrm{MH}$, Lewis K, Sutton S, Chan R, Turnbull AV, Lovejoy D, Rivier C, Rivier J, Sawchenko PE, Vale W (1995) Urocortin, a mammalian neuropeptide related to fish urotensin $I$ and to corticotropin-releasing factor. Nature 378: 287-292.

11. Wong ML, Al-Shekhlee A, Bongiorno PB, Esposito A, Khatri P, Sternberg EM, Gold PW, Licinio J (1996) Localization of urocortin messenger RNA in rat brain and pituitary. Mol Psychiatry 1: 307-312.

12. Spina M, Merlo-Pich E, Chan RKW, Basso AM, Rivier J, Vale WW, Koob GF (1996) Appetite-suppressing effects of urocortin, a CRF-related neuropeptide. Science 273: 1561-1564.

13. Bittencourt JC, Vaughan J, Arias C, Rissman RA, Vale WW, Sawchenko PE (1999) Urocortin expression in rat brain: evidence against a pervasive relationship of urocortin-containing projections with targets bearing type 2 CRF receptors. J Comp Neurol 415: 285-312.

14. Weninger SC, Dunn AJ, Muglia LJ, Dikkes $P$, Miczek KA, Swiergiel AH, Berridge CW, Majzoub JA (1999) Stress-induced behaviors require the corticotropin-releasing hormone $(\mathrm{CRH})$ receptor, but not CRH. Proc Natl Acad Sci USA 96: 8283-8288.

15. Behan DP, De Souza EB, Lowry PJ, Potter E, Sawchenko P, Vale WW (1995) Corticotropin-releasing factor (CRF) binding protein: A novel regulator of $\mathrm{CRF}$ and related peptides. Frontiers in Neuroendocrinol 16: 362-382.

16. Bornstein SR, Webster EL, Torpy DJ, Richman SJ, Mitsiades N, Igel M, Lewis DB, Rice KC, Joost HG, Tsokos M, Chrousos GP (1998) Chronic effects of a nonpeptide corticotropin-releasing hormone type 1 receptor antagonist on pituitary-adrenal function, body weight, and metabolic regulation. Endocrinology 139: 1546-1555.

17. Deak T, Nguyen KT, Ehrlich AL, Watkins LR, Spencer RL, Maier SF, Licinio J, Wong ML, 
Chrousos GP, Webster E, Gold PW (1999) The impact of the nonpeptide corticotropin-releasing hormone antagonist antalarmin on behavioral and endocrine responses to stress. Endocrinology 140: 79-86.

18. Timpl P, Spanagel R, Sillaber I, Kresse A, Reul JMHM, Stalla GK, Blanquet V, Steckler T, Holsboer F, Wurst W (1998) Impaired stress response and reduced anxiety in mice lacking a functional corticotropin-releasing hormone receptor 1. Nature Gen 19: $162-166$

19. Smith GW, Aubry JM, Dellu F, Contarino A, Bilezikjian LM, Gold LH, Chen R, Marchuk Y, Hauser C, Bentley CA, Sawchenko PE, Koob GF, Vale W, Lee KF (1998) Corticotropin releasing factor receptor 1-deficient mice display decreased anxiety, impaired stress response, and aberrant neuroendocrine development. Neuron 20: 1093-1102.

20. Liebsch G, Landgraf R, Engelmann M, Lörscher P, Holsboer F (1999) Differential behavioural effects of chronic infusion of $\mathrm{CRH} 1$ and $\mathrm{CRH} 2$ receptor antisense oligonucleotides into the rat brain. $J$ Psychiatr Res 33: 153-163.

21. Radulovic J, Rühmann A, Liepold T, Spiess J (1999) Modulation of learning and anxiety by corticotropinreleasing factor (CRF) and stress: differential roles of CRF receptors 1 and 2. J Neurosci 19: 5016-5025.

22. Lee S, Rivier C (1997) Alcohol increases the expression of type 1 , but not type $2 \alpha$ corticotropin-releasing factor (CRF) receptor messenger ribonucleic acid in the rat hypothalamus. Mol Brain Res 52: 78-89.

23. Makino S, Takemura T, Asaba K, Nishimura M, Takao T, Hashimoto K (1997) Differential regulation of type- 1 and type- $2 \alpha$ corticotropin-releasing hormone receptor mRNA in the hypothalamic paraventricular nucleus of the rat. Mol Brain Res 47: 170-176.

24. Coste SC, Kesterson RA, Heldwein KA, Stevens SL, Heard AD, Hollis JH, Murray SE, Hill JK, Pantely GA, Hohimer AR, Hatton DC, Phillips TJ, Finn DA, Low MJ, Rittenberg MB, Stenzel P, Stenzel-Poore MP (2000) Abnormal adaptations to stress and impaired cardiovascular function in mice lacking corticotropin-releasing hormone receptor-2. Nat Genet 24: 403-409.

25. Bale TL, Contarino A, Smith GW, Chan R, Gold LH, Sawchenko PE, Koob GF, Vale WW, Lee KF (2000) Mice deficient for corticotropin-releasing hormone receptor-2 display anxiety-like behaviour and are hypersensitive to stress. Nat Genet 24: 410-414.

26. Smagin GN, Howell LA, Ryan DH, De Souza EB, Harris RBS (1998) The role of $\mathrm{CRF}_{2}$ receptors in corticotropin-releasing factor- and urocortin-induced anorexia. Neuroreport 9: 1601-1606.

27. Kishimoto T, Radulovic J, Radulovic M, Lin CR, Schrick C, Hooshmand F, Hermanson O, Rosenfeld MG, Spiess J (2000) Deletion of crhr2 reveals an anxiolytic role for corticotropin-releasing hormone receptor-2. Nat Genet 24: 415-419.

28. Smagin GN, Howell LA, Redmann S Jr, Ryan DH, Harris RBS (1999) Prevention of stress-induced weight loss by third ventricle CRF receptor antagonist. Am J Physiol 276: R1461-1468.

29. Hotta M, Shibasaki T, Arai K, Demura H (1999) Corticotropin-releasing factor receptor type 1 mediates emotional stress-induced inhibition of food intake and behavioral changes in rats. Brain Res 823: 221-225.

30. Müller MB, Keck ME, Zimmermann S, Holsboer F, Wurst W (2000) Disruption of feeding behavior in $\mathrm{CRH}$ receptor 1-deficient mice is dependent on glucocorticoids. Neuroreport 11: 1963-1966.

31. Rühmann A, Bonk I, Lin CR, Rosenfeld MG, Spiess J (1998) Structural requirements for peptidic antagonists of the corticotropin-releasing factor receptor (CRFR): development of CRFR2beta-selective antisauvagine-30. Proc Natl Acad Sci USA 95: 1526415269.

32. Pelleymounter MA, Joppa M, Carmouche M, Cullen MJ, Brown B, Murphy B, Grigoriadis DE, Ling N, Foster AC (2000) Role of corticotropin-releasing factor (CRF) receptors in the anorexic syndrome induced by CRF. J Pharmacol Exp Ther 293: 799-806.

33. Makino S, Nishiyama M, Asaba K, Gold PW, Hashimoto K (1998) Altered expression of type 2 $\mathrm{CRH}$ receptor mRNA in the VMH by glucocorticoids and starvation. Amer J Physiol 275: R1138-R1145.

34. Nishiyama $M$, Makino $S$, Asaba $K$, Hashimoto $K$ (1999) Leptin effects on the expression of type-2 CRH receptor mRNA in the ventromedial hypothalamus in the rat. $J$ Neuroendocr 11: 307-314.

35. Makino S, Asaba K, Nishiyama M, Hashimoto $K$ (1999) Decreased type 2 corticotropin-releasing hormone receptor mRNA expression in the ventromedial hypothalamus during repeated immobilization stress. Neuroendocrinology 70: 160-167.

36. Richard D, Rivest R, Naimi N, Timofeeva E, Rivest S (1996) Expression of corticotropin-releasing factor and its receptors in the brain of lean and obese Zucker rats. Endocrinology 137: 4786-4795.

37. Ohta H, Suzuki K, Oki Y, Shibasaki T (2000) Urocortin in the ventromedial hypothalamic nucleus acts as an inhibitor of feeding behavior in rats. Brain Res 861: 1-7.

38. Eghbal-Ahmadi M, Avishai-Eliner S, Hatalski CG, Baram TZ (1999) Differential regulation of the expression of corticotropin-releasing factor receptor type 2 (CRF2) in hypothalamus and amygdala of the immature rat by sensory input and food intake. $J$ Neurosci 19: 3982-3991.

39. Sutton RE, Koob GF, Le Moal M, Rivier J, Vale WW (1982) Corticotropin releasing factor produces bahav- 
ioural activation in rats. Nature 297: 331-333.

40. Dunn AJ, File SE (1987) Corticotropin-releasing factor has an anxiogenic action in the social interaction test. Hormone Behav 21: 193-202.

41. Swerdlow NR, Geyer MA, Vale WW, Koob GF (1986) Corticotropin-releasing factor potentiates acoustic startle in rats: blockade by chlordiazepoxide. Psychopharmacol 88: 147-152.

42. Britton DR, Koob GF, Rivier J, Vale WW (1982) Intraventricular corticotropin-releasing factor enhances behavioral effects of novelty. Life Sci 31: 363-367.

43. Berridge CW, Dunn AJ (1989) CRF and restraintstress decrease exploratory behavior in hypophysectomized mice. Bioch Behav 34: 517-519.

44. Habib KE, Weld KP, Rice KC, Pushkas J, Champoux M, Listwak S, Webster EL, Atkinson AJ, Sculkin J, Contoreggi C, Chrousos GP, McCann SM, Suomi SJ, Higley JD, Gold PW (2000) Oral administration of a coreticotropin-releasing hormone receptor antagonists significantly attenuates behavioral, neuroendocrine, and autonomic responses to stress in primates. Proc Natl Acad Sci USA 97: 6079-6084.

45. Schulz DW, Mansbach RS, Sprouse J, Braselton JP, Collins J, Corman M, Dunaiskis A, Faraci S, Schmidt AW, Seeger T, Seymour P, Tingley FD III, Winston EN, Chen YL, Heym J (1996) CP-154,526: A potent and selective nonpeptide antagonist of corticotropin releasing factor receptors. Proc Natl Acad Sci USA 93: 10477-10482.

46. Griebel G, Perrault G, Sanger DJ (1998) Characterization of the behavioral profile of the non-peptide CRF receptor antagonist CP-154,526 in anxiety models in rodents: comparison with diazepam and buspirone. Psychopharmacology 138: 55-66.

47. Okuyama S, Chaki S, Kawashima N, Suzuki Y, Ogawa S, Nakazato A, Kumagai T, Okubo T, Tomisawa K (1999) Receptor binding, behavioral, and electrophysiological profiles of nonpeptide corticotropin-releasing factor subtype 1 receptor antagonists CRA1000 and CRA1001. J Pharmacol Exp Ther 289: 926-935.

48. Brown MR, Fisher LA, Spiess J, Rivier C, Rivier J, Vale WW (1982) Corticotropin-releasing factor: actions on the sympathetic nervous system and metabolism. Endocrinology 111: 928-931.

49. Brown MR, Gray TS, Fisher LA (1986) Corticotropin-releasing factor receptor antagonist: effects on the autonomic nervous system and cardiovascular function. Reg Pept 16: 321-329.

50. Nijsen MJMA, Croiset G, Stam R, Bruijnzeel A, Diamant M, de Wied D, Wiegant VM (2000) The role of the CRH type 1 receptor in autonomic responses to corticotropin-releasing hormone in the rat. Neuropsychopharmacology 22: 388-399.

51. Kageyama K, Gaudriault GE, Bradbury MJ, Vale WW (2000) Regulation of corticotropin-releasing factor receptor type 2 beta messenger ribonucleic acid in the rat cardiovascular system by urocortin, glucocorticoids, and cytokines. Endocrinology 141: 22852293.

52. Asaba K, Makino S, Nishiyama M, Hashimoto $K$ (2000) Regulation of type-2 corticotropin-releasing hormone receptor mRNA in rat heart by glucocorticoids and urocortin. Cardiovasc Pharmacol 36: 493497.

53. Heldwein KA, Duncan JE, Stenzel P, Rittenberg MB, Stenzel-Poore MP (1997) Endotoxin regulated corticotropin-releasing hormone receptor 2 in heart and skeletal muscle. Mol Cell Endocrinol 131: 167-172.

54. Makino S, Asaba K, Takao T, Hashimoto K (1998) Type 2 corticotropin-releasing hormone receptor $\mathrm{m}$ RNA expression in the heart in hypertensive rats. Life Sci 62: 515-523.

55. Ikeda K, Tojo K, Sato S, Ebisawa T, Tokudome G, Hosoya T, Harada M, Nakagawa O, Nakao K (1998) Urocortin, a newly identified corticotropin-releasing factor-related mammalin peptide, stimulates atrial natriuretic peptide and brain natriuretic peptide secretions from neonatal rat cardiomyocytes. Biochem Biophys Res Commun 250: 298-304.

56. Nozu T, Martinez V, Rivier J, Tache Y (1999) Peripheral urocortin delays gastric emptying: role of CRF receptor 2. Am J Physiol 276: G867-874.

57. Martinez V, Barquist E, Rivier J, Tache Y (1998) Central CRF inhibits gastric emptying of a nutrient solid meal in rats: the role of CRF2 receptors. Am J Physiol 274: G965-970.

58. Singh LK, Boucher W, Pang $X$, Letourneau $R$, Seretakis D, Green M, Theoharides TC (1999) Potent mast cell degranulation and vascular permeability triggered by urocortin through activation of corticotropin-releasing hormone receptors. J Pharmacol Exp Ther 288: 1349-1356. 